\title{
Textual Analysis of James Joyce's Dubliners: A Fanonian Reading
}

\author{
FERHI Samir \\ English Department \\ Faculty of Letters and Languages \\ Mouloud MAAMERI University of Tizi Ouzou, Algeria \\ Email: samirferhi18@gmail.com
}

Received: 10/18/2020

Accepted: $1 / 27 / 2021$

Published: $2 / 24 / 2021$

\begin{abstract}
This research paper explores Joyce's textual resistance to the Celtic Revivalism and the Irish Catholic conservatism in Dubliners (1914). Using postcolonial theories like the one proposed by Frantz Fanon in his The Wretched of the Earth (1968), the research shows that in writing Dubliners, Joyce, unlike the Irish Revivalist authors and conservative Catholics, was more interested in showing the imperial force or power in all shades, and put the blame on the lethargy of people when it needs to be placed, whether on imperial Britain, the Revivalist authors or the Irish Catholic conservatism. The paper also makes the case that if the colonial pathology of paralysis is the central theme of Joyce's Dubliners, nevertheless, the power to resist or the resistance strain against this pathology is another essential idea explored by Joyce in his collection of short stories.

Keywords: Dubliners, Catholic conservatism, Fanon, Joyce's textual resistance, Revivalism

Cite as: FERHI, S. (2020). Textual Analysis of James Joyce's Dubliners: A Fanonian Reading. Arab World English Journal for Translation \& Literary Studies 4 (4) 60-71.

DOI: http://dx.doi.org/10.24093/awejtls/vol5no1.4
\end{abstract}




\section{Introduction}

Resistance to the diverse forms of power is widely used by scholars in contexts of domination straddling across the lines of class, gender, and race, to date; a small case seems to have been made of it by critics in their analysis of Joyce's Dubliners (1914). In scholarly works, as varied in their approach like Schwarze (2002), Thurston (2004), Kibred (2006), Bulson (2006), Parsons (2007), Nash (2009), to cite but a few, have placed the focus much more on paralysis as pathology than resistance as the predominant theme of Joyce's work. Indeed, if Joyce exposed in his fiction the paralytic state and conditions of life in colonial Ireland, which exerted such a strong influence on critics, the abuse of power has been a little bit overlooked or missed. Reading the vast volumes of critical literature available on The Dubliners shows that most critics have made short shrift of such authors and essayists as Lawrence, who advises the readers to believe much more the tale rather than the one, who yarns it. As such, the following research, while recognizing that indeed paralysis constitutes one of the major themes of Joyce's collection of stories; gives heed to its exploration of the resistance to the colonial pathologies caused by British imperialism, the parochialism of the Celtic revivalists, and the conservatism of the Catholic Church.

\section{Methods}

In exploring the resistance strain in Joyce's Dubliners, the study uses Fanon's (1968) writings on colonialism, its pathologies, and the forms of resistance to the latter. In The Wretched of the Earth, Fanon divides the evolution of the colonial literature into three distinct phases: the assimilation phase, the return to the source phase, and the combative phase. In the first phase, as he puts it, the "native intellectual gives proof that he has assimilated the culture of the occupying power" ( $p, 222)$. The native's inspiration is the same as that of his counterparts of the so-called mother country, in our case, colonial England. In other terms, the native intellectual follows in the footsteps of these countries in matters of literary movement and style. It treats more or less the same themes using the same imagery that the colonized employ to depict the native. The comic image of the Irishman and the figure of "Paddy" illustrate unwittingly the native Irish authors, who seek to place themselves in the literature of the "mother country."

The second stage in the evolution of the colonized literature, Fanon (1968) goes on with his categorization, is a stage marked by a return to the sources when the native intellectual or writer finds out that colonialism, notwithstanding the assimilation policy, does not allow the natives to assimilate themselves because that would mean the defeat of its initial project, which is financial exploitation. Blatant colonial, economic exploitation, we understand, passes through the strategy of dehumanization. At the stage of the literature of the return to the sources, the native author, Fanon (1968), tells us, is "disturbed. He decides to remember what he is" (p, 222). This remembrance takes on a nostalgic turn as the naive author, debarred from the access to the desired status as an assimilated or integrated author, to use a present-day terminology, remembers the "bygone days of his childhood" and the old legends and myths of his community. Fanon (1968) underscores the fact that this return to the source occurred with the aesthetic tools and a conception of the world "discovered under new skies" ( $p, 223)$, i.e. the colonial mother country. As it will be 
shown very shortly, the Celtic Revival or the Irish Literary Renaissance is placed in this second phase of the evolution of colonial literature. Joyce makes the same critique of the Irish revivalists as the one that Fanon thrusts at the colonized native authors.

Fanon (1968) calls the third phase in the evolution of the literature of the colonized "the fighting phase." Fanon might have borrowed the term "combat" from Sartre's (1948), but he appropriates it to fit in with the colonial writer's and the latter's mission. For him, the literature of combat, or the "literature of commitment" deserves to be categorized as such not by the fact that the native author decides to "lose himself in the people and with the people" $(p, 223)$ in the manner of those who seek contact with the popular sources after their disappointment with the ideological decay of assimilation. On the contrary, Fanon (1968) proposes that "instead of according the people's lethargy an honored place in his esteem, he [the colonized writer] turns himself into an awakener of the people," by producing a "fighting literature, a revolutionary literature, and a national literature" (p. 223), not the one that emphasizes a dying ethnic or national culture in a heavily borrowed aestheticism and a world view developed in the mother country.

\section{Results}

Whatever the emphasis Joyce has placed on colonial pathology and paralysis, or lethargy of the people as Fanon (1968) calls it, he can be called an awakener by the simple fact of raising the issues of the imperial power of all shades and putting the blame for the lethargy of the people. Much more importantly, Joyce's stories of Dubliners (1914) deserves to be arranged in the shelves of fighting, revolutionary, or national literature because of its critical resistance to fall into the trap of seeking to return to the 'dying' and 'deformed' sources that characterize the Celtic Revivalist authors, or make his own the clichés of the British imperial literature on Ireland, or espouse the conservatism of the Catholic Church. This triple-edged critical resistance in Dubliners is inscribed dialectically with the notion of paralysis.

A first question comes to mind at this early stage. How does Joyce criticize the very cultural nationalisms, the fundamental goal to "decolonize the mind," the words are Ngugi's? (1986). To answer this question and give examples to illustrate our point, it is essential to go back to Fanon again. Fanon (1968) claims that the native authors' belonging to the first two phases of the literature of the colonized, the stage of assimilation and that of the return to the sources, failed to cope with the mental and the physical domination of the colonizer, so they appropriated unthinkingly the assumptions of their native cultural inferiority that the colonial powers had initially deployed to hold their sway over the colonial people and to justify the colonial presence in the conquered territories. In this case, it is the Celtic Revivalist Movement to which Joyce refers in Dubliners since it nuances a little bit Fanon's argument about the colonized nationalist pitfall consisting of replicating the assumptions of the colonizer.

\section{Discussion of the Short Stories}

Arab World English Journal for Translation \& Literary Studies 
The Celtic Revivalist Movement, as Boyd (2007) reminds us, came into existence as a result of the failure of the politics of the Homeland movement initiated by Charles Stuart Parnell because of his moral scandal of adultery with a British married woman, who was the wife of a very prominent British politician. This scandal divided the Homeland Movement and caused the end of Parnell with his cross-ethnic and cross-religious nationalism on moral grounds. Boyd argues that after the demise of Parnell and his political movement, there emerged in Ireland a site of ideological combat to resist the Irish cultural alienation. The Gaelic language, the Irish traditional sports, and all types of cultural manifestations (theatre, poetry, and prose literature) are elevated into forms of affirmation of the Irish identity. We would argue that this affirmation of Irish identity as a means for "decolonizing the mind," i.e., of restoring the full humanity of the Irish people in their own eyes as well as in the eyes of those who colonized them, has all the pitfalls associated with the restorative nostalgia associated with Fanon's second phase in the evolution of the literature of the colonized, which disappointingly and despairingly seeks a return to the sources. Thus, cultural nationalism, as advocated by Celtic Revivalists such as the distinguished Yeats and Gregory, who are interested in the nostalgic restoration and celebration of an authentic culture of Ireland, regardless of the developments of history and the linguistic as well the cultural hybridity that ensued through the long, imposed contact of the Irish people with all the diverse ethnic invaders who had migrated to Ireland. What is more severe in the cultural nationalism advocated by the Celtic Revivalists is not solely the assumption that the Irish as a presumably national group had at their disposal a pure and radically different civilization from that of the colonizers that they could reclaim through just a power of the will, but the degree to which this nostalgic return to the sources is derived and replicates the images and assumptions of the colonizer.

Hence, we find out Yeats (1933)- the most prominent cultural figure of the Irish Renaissance and the least liable to critique in Joyce's eyes - reproducing the colonial clichés of the Irish life as penetrated by mysticism, complaining of the dilemma in which he is caught, as illustrated in his poem "Dialogue of Self and Soul": "How in the name of heaven can he escape/That defiling and disfiguring shape/The mirror of malicious eyes/Cast upon his eyes until at last/ He thinks that shape must be his shape" (Yeats, 1933, p. 89). The inability of Yeats to escape the deforming gaze of the colonizer is captured in this poem where he acknowledges that his return to the so-called mystical and primitive sources of Irish life, though undertaken in the English language, is performed in terms dictated by the authors of the mother country.

Arnold (1904) is arguably the most representative British author who contributed establishing the binary system of colonial thought between the English and Irish. His attitude to the Irish or Celts, as demonstrated in his lectures advocating a Chair of Celtic Studies at Oxford, was admittedly more amiable than that of Benjamin Disraeli dismissing the Irish as a people who "hate our order, our civilization, our enterprising industry, our sustained courage, our decorous liberty, our pure religion" (Curtis, 1968, p, 84). Kingsley goes further in this dismissal of the Irish as mentally disabled people by racially categorizing them as "human chimpanzees," "white chimpanzees," dreadful to look at, just because their skin pigmentation, is "as white as ours [white 
Anglo-Saxons']" (p, 85). However, if Arnold (1904) departs from this crass racialism, he remains very paternalistic in his description of what he sees as an Irish essence. For him, the Anglo-Saxon sense of honesty, industry, order, etc., contrasts markedly with the Celtic sentiment, sensitivity to joy and sorrow. The Irish nature, in his words, is to "aspire ardently afterlife, light, and emotion, to be expansive, adventurous and gay[...]He loves bright colors, easily becomes audacious, overcrowding, full of fanfaronade [...]He is always ready to react against the despotism of fact (Arnold's emphasis), [but lacking] balance, measure, and patience" (pp, 76-78).

Joyce's resort to depicting the Irish people's lethargy or paralysis in Dublin is a critical attitude of resistance to the excessive idealization, the romanticizing, and the mystification of the Celts and Ireland the authors belonging to the Irish Renaissance. For example, the Irish romantic love, epic poetry, mystic peasant life celebrated in Yeats's The Wandering of Oisin, the Island of Statutes, Masada, The Seeker, Countess Kathleen, and Various Legends and Lyrics, The Death of Cuchullin, and Fergus and the Druid are tellingly absent in Dubliners (1914). Obviously, in the urban setting of Dublin that Joyce depicts for us, the magical realism of the literature and drama of the Irish Renaissance has no hold on the reality of the Irish colonial people. The romantic life of such heroines such as Countess Cathleen and the epic struggle of Cutchullin give place to a portrayal of the stunted emotional life of characters, such as the narrator boy and the paralytic Father Flynn in The Sisters. The domestic and public life of the Irish was overwhelmed by unbearable violence that contrasts the innocent, pastoral life which the Abbey Theatre wished to hold as a mirror before an alienated, demoralized, devitalized, and stunted people. Unsurprisingly, therefore, after two decades of mystification with the narrow cultural nationalism of the Celtic revivalists and the traditional drama of the Yeatsian type, Synge provoked a riot in Dublin by presenting a less rosy and archetypal picture of Countess Cathleen in his play The Playboy of the Western World (1906). Written nearly at the same time as Synge's play, Joyce's Dubliners took ten years before its appearance. This delay in publication was caused by the same fear of scandal that Joyce's exhibition of the seamy side of the purlieus of Night Town Dublin might have provoked.

One of the forms of resistance that Joyce showed in publishing Dubliners is his refusal to abide by the lines of the publishers who asked him to make the book fit in with the expectations of the audience. In this refusal to comply with censorship, which does not say its name, Joyce comes very close to his contemporary Irish dramatist Synge, who, by refusing to toe the moral line of the Abbey Theatre, had to wait until 1963 to have his play, The Play Boy of the Western World, staged in its original version in Dublin. Joyce was much luckier because his Dubliners saw the light with just minor changes in 1914. The resistance undertaking alteration of the Dubliners' storyline is a means through which the Irish could have "one good look at themselves in my nicely polished looking-glass" (Joyce, as cited in Ellmann, 1957, p, 18). It is in this concern with not preventing the Irish people from having one "good look at themselves in my nicely polished looking-glass" that we see Joyce in his full stature as an awakener of the Irish people, who are alienated by the narrow cultural nationalism of the Celtic Revivalist movement. However, just like Fanon, Joyce puts a caveat to this cultural nationalism because an obsessive concern with the pre- 
colonial heritage of the people could prevent the "hope for a future national culture" by diverting the people's attention from the way they should proceed to change the contemporary economic, political, and socio-cultural events and issues that stifle their life and block a healthier vision of life. By putting his finger on the sore point of contemporary Irish urban life in all its aspects, Joyce disturbs the Irish people's lull and easy indulgence in restorative nostalgia. In other words, Joyce's scalpel is dug in the festering colonial wound to awaken the Irish people to the painful reality of their nation by inviting them to move forward in the building of their country. In this regard, Hobsbawn (1973) says:

At the very moment when the native intellectual is anxiously trying to create an artistic work he fails to realize that he is utilizing techniques and language which are borrowed from the stranger in the country. [...] The artist who has decided to illustrate the nation's truth turns paradoxically towards the past and away from actual events. [...] But the native intellectual who wishes to create an artistic work of art must realize that the nation's truths are in the first place its realities. (pp, 180-181)

By insisting on the urban reality of Night Town Dublin, in Dubliners, Joyce (1914) prefigures Fanon's claim that an original work of art is the one that foregrounds the facts of the nation, no matter their harshness. In rescinding the restorative nostalgia of a heroic, romantic past of Ireland, Joyce resists the heavy pressure of the consensual opinions of the Irish literary establishment. In a nutshell, this study counter-claims those scholars who have over-generalized the Fanonian dimension of Joyce, which, if it could certainly not be denied, has at least to be qualified in the light of what had been already saying about Joyce's relationship with Fanon. What saves Joyce from being rejected the company of Fanon is that he is as critical in his Dubliners, of the same petty Irish bourgeois in colonial Ireland as Fanon is of the native Algerian urban 'bourgeois' class. The government clerks, the teachers, the tram drivers, the bar curators, the men-about-town, the priests, the landladies, landlords, and the miners, are typical of the 'Irish bourgeois proletariat' are not spared the ironic thrusts of Joyce. In this regard, Gibson (2006) argues that "Unlike, say, Zola, Joyce did not write about the urban poor, or directly address their concerns. But he was aware that the economic distinction between the characters in the novels and the classes beneath them was small and precarious. (p. 69)" Gibson does not realize that even this small difference in status and rank, that is to say, privileges between the poor and the petty-bourgeois, was the one that led to the failure of the Irish political class to resist the British conqueror and blaze their way to independence. It can even be said that Joyce's neglect of the peasantry in Dubliners, an aspect very prominent in Irish revivalist literature, could not solely be accounted for by Joyce's abjuration of the pastoralism of the Celtic Revival, but in his incapacity to realize the revolutionary force of the peasantry, and the interaction between the town and the city in the fermentation of revolution.

It has to be noted that in his shaping of characterization, Joyce relies mostly on typicality and irony as defined by Lukacs (1978). Irony, as Lukacs writes it so well, is a characteristic of modern prose, particularly the novel. In his Reader's Guide to James Joyce, Tindall (1979) writes the following concerning this technical aspect of Dubliners, "as for satire, with which we feel at home when we meet it in George Orwell, there is none of it in Dubliners. There is no sign here of 
indignation and what, we ask, is morality without this?" (p. 92) Tindall is to the point in posing this question because Joyce initially at least has told his publishers that in Dubliners he has set out to write the "moral history of Ireland," which he regards as the first step toward its "spiritual liberation." However, Tindall's characterization of Joyce's writing style is ironic. Here, the major problem is that he does not tell us what type of irony Joyce deploys in his stories to rewrite the moral history of his country. Thus, for Frye (1990), the irony is a mode of writing corresponding to that type of characterization wherein the hero or heroine is below his human and natural environments (pp. 132-239). The other modes corresponding in his scheme to the hero's status are the mythic, the romantic, the high mimetic, and the low mimetic, wherein irony predominates and takes us back to myth. In this sense, all of the petty Irish bourgeoisie are below their human and natural environment, both colonized and incapable of struggling against the moral and physical dunghills that speak so much of their renunciation to the anti-colonial resistance to the British conqueror and the Roman Church.

So there are peculiarities in Joyce's deployment of irony, which, if ever overlooked in our critique of the Dubliners, can lead to a lot of misleading conclusions as regards his anti-colonial resistance to imperial rule, in its religious and colonial shades. What Tindall (1979) has paid little attention to in his clear-tight distinction between satire and irony is that "satire" as Frye (1990) puts it so well is "militant irony: its moral norms are relatively clear, and it assumes standards against which the grotesque and absurd are measured" (p. 223)". This militant attitude toward the grotesque situations used by Joyce is to the point when he writes that he sets out to write the moral history of Ireland, which most critics inadvertently have overlooked in their concentration of the dunghills and the scatological vision of the country. As a city, Dublin reminds us not only about the modern Western towns to which it unfavorably compares itself but also to mythological and Biblical cities like Egypt and Babylon. The Irony, as we have already said, following Frye's lead, takes us back to myth, if there is one city to which Dublin is compared on a mythological scale, it is that of Babylon, wherein the Jews were kept captives after the sack of Jerusalem for a second time in their history during the seventh and sixth century B.C.

The first example of Joyce's anti-colonial resistance to British imperialism and the conservatism of the Catholic Church is shown in the opening story "The Sisters," as the reader is attracted by the first sentence for its moral and existential significance, "There was no hope for him this time: it was the third stroke." (Joyce, 1996, p.1) In the context of the story, this sentence is related to the death of a disabused, mad, and paralytic priest James Flynn who died of a third stroke, which can also as the third stroke of a tolling bell. However, the reader cannot lose the reference to Dante's (1935) Divine Comedy, the first sentence of which inscribed on the lintel of the entrance gate to hell also reads, "Abandon all hope, all who enter here." (p. 321) It follows that Joyce, deeply steeped in Italian literature and moral tradition inscribed by Dante. Reference to sin and good suffering is made in the same book. Yet, contrary to Dante, Joyce puts the mad and paralytic priest and his two senile sisters at the very crux of the paralysis of the Irish colonial society. Joyce even parodies the mass for the dead at the end, and the unnamed boy who is witness 
to the demise of the priest, himself incapable of bearing all the life-denying institutional rituals of the Catholic Church, is glad to have escaped the grip of Father Flynn by not having chosen a church vocation. It is said that the deceased priest James Flynn with the wide-open, haired nostrils and big discolored teeth with his tongue lying upon his lower lip is what James Joyce (note the similarity in forename) is imagining his future energy to be if he had decided to trade off the life as a writer.

In this particular case, there is no Beatrice figure to lead him to his vocation of writer as Virgil/Dante himself is fortunate enough to have. All he has as a guide in the hell and inferno of Dublin are three old, sinister women (his old aunt and James Flynn's two senile sisters) all, of them, looking like the three Graces of Greek mythology. Significantly, it is these senile nun sisters Nannie and Eliza who ironically give the title to the opening story and which set the tone for the colonial life that awaits the Irish colonial. It is also the "ideal priest/ Reverend" Father Flynn who provides a perfect foil for the Galahad of the stories of the Holy Grail, who does not only fail in his mission by breaking the chalice but also ends the whole story with reported fits of delirium.

In "After the Race," Joyce is not interested in the rural or urban proletariat, but what Fanon calls the corrupt and corrupted petty-bourgeois class, happy with the crumbs that can be gathered from under the table of the holders of the empire. It is in this tale that Joyce describes the Irish class that stands for a formidable and insuperable impediment to a real revolution. The story, as the title suggests, is a car race organized in colonial Ireland. Still, it is intended primarily as a typical illustration of the colonization of the Irish mind and the necessity to decolonize it. As the excited sightseers are gathered on the borders of the road leading to Dublin to watch the car race, Joyce (1914) writes, "Now and again," he tells us tongue in cheek. Their sympathy, however, was for the blue cars - the cars of their friends, the French. (p.40)" Joyce shows how these "gratefully oppressed" fell in adoration of the car produced under other skies in the French Empire. Transformed into a fetish by an Irish colonial people, this blue French car is said to carry "a cargo of hilarious youth," (p.41) with the French driver Charles Ségouin at the wheel, and the rest of the passengers consisting of three of colonials, a Canadian, a Hungarian, and an Irish man to be joined later by an American, another imperial man. At the end of the story or rather the end of the day, that is to say after the race, it is the Irish man, the social climber Jimmy, a son of a wealthy butcher, who squanders all his hard got money in celebration of the victory in the American's yacht. The militant attitude of Joyce is shown in his rejection of Jimmy's wasteful expenditure of wealth and recognition from those imperial holders bent to reduce the colonial people into fetish believers in the latest technology.

"Counterparts," the eighth story in the collection, is arguably the most famous story in terms of the militant attitude of Joyce toward colonialism. Three actors peculiar to the Irish colonial context are evoked: Farrington, the Irish scrivener clerk, Mr. Alleyne (note the title), who belongs to the Irish Ascendancy from the North of Ireland, and the absentee owner of the legal firm Crosby, who is also the associate of Mr. Alleyne. In this story, the harassment that Farrington experiences 
at the hands of Mr. Alleyne, a bullying, short, bald man "wearing gold-rimmed glasses on a cleanshaven face," who never misses an occasion to humiliate Farrington in front of all the other secretaries. No longer able to save up his face, Farrington has no way but to go to a pub to drink out his resentment with the six shillings he earns by pawning his watch at Fleet Street. However, even in the pub, after having proudly recounted to the other clients how he has put his master in his place, he loses his arms-wrestling match with Weathers. As such, and instead of confronting the colonial presence by looking its representatives in the face, the Irish males flee to the pub just as the case with comic-stage Irish men that are often meet in Anglo-Irish literature.

Humiliated in the presence of their colonial superiors, the Irish males became tyrants in their homes. Hence, Farrington goes back home so drunk that he does not recognize to which son of his he is speaking. "Who is that?" Said the man. (Note the irony. Farrington is the man only at home.) "Who are you, Charlie?" (Joyce, 1996, p.96). Transferring the violence that he had bottled up all day long, Farrington "seized the walking-stick which was standing" (p, 97) in the hearth with the fire out and bet his son. Farrington, now symbolically, and ironically called the man, slashed at "the boy" who "uttered a squeal of pain and the stick cut his thigh. (p. 96) In response to the cruelty of the humiliated colonized man, the son, as if appealing to the God Father, says what follows: "Oh! pa! He cried. Don't beat me, pa! And I," or "I'll say a Hail Mary for you, pa if you don't beat me." (p. 97) The Irish man has nothing to turn to but to the sanctuary of religion or the Ave Maria prayer. Instead of taking his destiny in his hand in the face of colonial browbeating and act like the man that he is supposed to be in the public sphere, he transfers the violence he experiences at the hands of his superiors into the private sphere. We would argue that Farrington swallows his dignity as a man in the public space because of his privileged position as a petty-bourgeois clerk in a law firm owned by an absentee lawyer.

In "The Dead," there is no less condemnatory of the flaws of the Irish colonial society, as the story deals with a customary end-of-the-year Irish reunion-a kind of Shakespearean Twelfth Night (1602)-organized by two sisters the Misses Morgan's for the benefit of family and friends, the focus will be put on the intertextual dimension of the tableau of Romeo and Juliet hanging on one of the walls of Misses Morgan's home in the balcony scene of the story. The reader remembers that near the middle of the story, there is Gabriel who, wistfully looking at his wife standing in the first- floor balcony listening to the music notes of love Irish melody wafting from the drawingroom upstairs. It is in this particular scene that the tableau becomes real for Gabriel. For a brief moment, he thinks to have retrieved the love that he has never really felt for his wife, taking it for granted that he is her sole man in life. We see Gabriel getting fussy about quitting his sisters' home for a hotel nearby as if it is his honeymoon, having already dismissed offhand his wife's (Gretta's) idea of making a journey to Conway in the West of Ireland.

It is in the hotel room that Joyce thrusts his usual militant irony by offering an ironic counterpoint to the Romeo and Juliet legendary love story. Joyce has the husband tell his wife to explain why she gets so sad at the Irish melody before coming to the hotel. In the hotel room, she 
avows that she used to be an old flame for a love-stricken boy called Michael Furey. Furey's love has overwhelmed Gretta when she hears the Irish love melody called "The Lass of Aughrim," the favorite love song that Furey used to sing for her even on rainy days in the good old days. Egged on by Gabriel, Gretta tells him that if she is moved by the Lass of Aughrim, it is because she 'thinks that he [Furey] died for her." Suffering from consumption, he leaves his bed in the winter night for a serenade, catching a fatal cold while singing her favorite song at the border of the garden. What makes matters worse for her now is that during all the time of serenade she is packing up to leave Nuns' Island and Furey. Both of them stand looking at the snowcapped Wellington Monument across the street.

It is at this crucial moment in this story that the anecdote that Gabriel has told about his grandfather during the feast takes all its sense. Gabriel recounts to the audience that his grandfather, Patrick Morgan, a glue-boiler or starch mill owner by trade, used to have a horse named Johnny working in the mill by walking round and round the mill. One day his grandfather, out of patriotic zeal, no doubt, decides to participate in a "military review in the park. (Joyce, 1996, p.205)" As he goes on to add, his grandfather "harnessed Johnny and put on his very best tall hat and his very best stock collar in his grand style from his ancestral mansion somewhere near back lane. (p.205)" Gabriel recounts that "everything funny went on beautifully until Johnny came in sight of King Billy's statue: and whether he fell in love with the horse of King Billy sits on or whether he thought he was back in the mill, anyway he began to walk around the statue. (p. 206)". The horse as the colonial Irish harnessed to the mill while in English detention, just as the Jews in Egypt captivity, are so fascinated with their tormentor (King Billy is a reference to William of Orange, and his massacre of the Irish) that they cannot do otherwise than go around him in subjected adoration. Gabriel's imitation of his grandfather's horse as it walks or canters around King Bill's statue, in the galoshes the former bought from abroad is just one typical portrait of the colonized Irish males. Gabriel is disabled for love and he is shocked to learn that his wife used to be the flame of a man who died for her. Implicitly at least, Gabriel turns out to be so imprisoned in his colonial prejudices that he cannot risk his life for his beloved wife. Here is all the difference between Romeo and Furey on the one hand, and Gabriel on the other, who the moment he is told of the necessity "to die for his wife (Gretta/Lass of Aughrim) to deserve her love, he feels threatened in his manhood. As he takes his boots or galoshes as they are described, we realize through the sexual symbol they convey, the place where he stands regarding his anti-colonial resistance. "One boot," it is said, stood upright, it's limp upper fallen down [...while] the fellow of it lay upon its side" (p.60). The emasculation of this colonized elite man cannot be better put into relief than the phallic symbol of the galoshes of which he is so proud.

\section{Conclusion}

It follows from the above that Joyce, in Dubliners is not solely interested in paralysis, or colonial pathology, but also in the resistance strain by naming and shaming the failure of the petty Irish bourgeois class somewhat in the manner of Fanon in his The Wretched of the Earth (1968). Joyce in his peculiar way in his short stories collection, to use Fanon's words, wrote literature of combat

Arab World English Journal for Translation \& Literary Studies 
or committed literature by his emphasis on pitfalls of the colonized Irish petty bourgeoisie in the urban setting of Dublin. His shunning of the pastoral, a notable feature of the Irish Cultural Revivalist literature, shows to what extent he seeks to escape the return-to-the-sources literature phase in Fanon's categorization. The study has also explored how some Irish literary authors, as Yeats and Gregory as representative figures in their compliance with the anthropological clichés about the Irish circulated by English authors like Arnold. As for the assimilation phase, the first phase in Fanon's scheme of the colonized, Joyce makes a small case of it by developing a mode of writing that is called naturalist-symbolic, and which has some of its inspiration in French literature in both its classical and modern forms. All through the discussion, it is pointed out at typicality as defined by Lukacs and militant irony as described by Frye as two predominant characteristics of Dubliners. In militant irony, and typicality readers can locate Joyce's colonial resistance strain in Dubliners, whose critique of the Irish bourgeoisie proletariat makes Joyce prefigure the Fanon of The Wretched of the Earth.

\section{About the author:}

Dr. Ferhi is a teacher/ lecturer of English, American and Irish Literature/Civilisation in the English Department, Mouloud Mammeri University of Tizi Ouzou, Algeria. His main interests include media and film studies, comparative literature, postcolonial literature and gender. https://orcid.org/0000-0003-4446-1821

\section{References}

Boyd, E. (2007). Ireland's Literary Renaissance. Robarts: University of Toronto

Bulson, E. (2006). The Cambridge Introduction to James Joyce. Cambridge: Cambridge University Press

Curtis, L.P. (1968). Anglo-Saxons and Celts, Bridgeport Conn.: University of Bridgeport Press

Dante A. (1555). The Divine Comedy of Dante Alighieri: Inferno, Purgatory, Paradise. (1935),

New York: The Union Library Association. Retrieved from

https://search.liberary.wisc.edu/catalog/999798755402121

Fanon, F. (1968). The Wretched of the Earth. Trans. Constance Farrington, New York: Grove Press

Frantz, F. (1968). "On National culture" in The Wretched of the Earth. In Williams, P \& Chrisman, L, ed., \& intro., Colonial Discourse and Post-colonial Theory: A Reader, London: Harvester Wheatsheaf '1993), pp.36-52.

Foucault, M. (1978). The History of Sexuality (1988), $1^{\text {st }}$ Ed. New York, Vintage Books Frye, N. (1990). Anatomy of Criticism: Four Essays. New Jersey: Princeton University Press Gibson, A. (2006), James Joyce. London: Reaktion Books

Hobsbawn, E.J. The Passionate Whiteness, in the New York Review, (1973). Retrieved from ttps://www.nybooks.com/articles/1973/02/22/passionate-witness

Joyce, J. (1914), Dubliners (1996). London, Penguin Books

Joyce, J. Letters of James Joyce (1904). In Ellmann, R. (eds) The Critical Writing of James Joyce (1957), (pp, 18-145). Ithaca: Cornell University Press 
Lukacs, G. (1978) Studies in European Realism. Trans. Edith Bone, London: The Merlin Press Lukacs, G. (1971). The Theory of the Novel. Trans. Anna Bostock, Cambridge: The MIT Press Ngugui, J.W. (1986), Decolonizing the Mind: The Politics of Language in African Literature, 1993, Oxford, (ed) James Currey.

Tindall, W. (197). A Reader's Guide to James Joyce. New York: Syracuse University Press

Yeats, W. B. (1933) “A Dialogue of Self and Soul." In Richard J (ed).The Poems of W. B. Yeats, (1961), (p. 89), Finneran: Macmillan Publishing Company 